\title{
Micrometeorological Characteristics of a Rubber Plantation on Hainan Island, China
}

\author{
Hidenori Takahashi*, Kiyotaka NaKagawa**, Shuji Yamakawa***, \\ Yumiko TANAKA****, Yoshinori MAEdA*, Yonglu HAO***, Luonai XIE*****, \\ and Pintong ZENG*****
}

\begin{abstract}
Micrometeorological properties of rubber tree plantation were measured for three years from April 1986 to March 1989 in Hainan Island. Aerodynamic properties such as the effective height, the roughness parameter and zero-plane displacement and the penetration rate of radiation through the rubber tree canopy were clearly changed with fall and elongation of leaves and stems of rubber tree. Albedo of short-wave radiation above the canopy also changed from $10 \%$ in winter and spring to $16 \%$ in summer and autumn. The latent heat flux above the canopy have decreased drastically after leaf fall and sensible heat increased. The sensible heat flux on the forest floor was very small through the day. Heat loss due to negative net radiation was compensated by the soil heat flux during the night.
\end{abstract}

Key words: micrometeorlogy, radiation balance, rubber plantation, Hainan Island, China.

\section{INTRODUCTION}

Hainan Island is in the tropical and subtropical regions. The climate is characterized by high temperatures throughout the year, plentiful rainfall in summer and autumn, and frequent typhoons. The northern area suffers from the effects of polar cold air masses flowing in from the Siberian Plateau several times in winter. Rubber is the most important tropical crop in Hainan, and it is damaged by this cold air every few years. To establish methods to prevent or reduce this damage, micrometeorological observations were carried out in and outside a rubber plantation for three years, from April 1, 1986 to March 31; 1989.

Micrometeorological studies on rubber tree stands have been conducted by the South China Academy of Tropical Crops Science (SCATC) since the beginning of the 1980s (HAO, 1981;
XIE, 1982). These studies have developed into cooperative projects between Japan and China organized by M. Yoshino (Yoshino, 1986; TAKAHASH et al., 1986). GAO started studies of the heat balance in rubber plantations (GAO et al., 1986; HuANG et al., 1985). In these studies, there are not sufficient data (meteorological elements and length of observation) for a determination of the micrometeorology and heat balance. The authors have reported the effects of windbreaks in and above rubber tree stands. Aerodynamic properties of wind and radiative properties of rubber tree stands with data covering one year and the same system as in this and previous papers (TAKAHASH et al., 1988a, 1988b; NAKAGAWA et al., 1988a, 1988b). In this paper, the micrometeorological characteristics of rubber tree stands, heat balance, radiative and aerodynamic properties are analyzed with data for three years.

\footnotetext{
*Environmental Science, Hokkaido University, Sapporo, Hokkaido 060

** Joetsu University of Education, Joetsu, Niigata 943

***Institute of Geoscience, University of Tsukuba, Tsukuba, Ibaraki 305

****College Experimental Forest, Hokkaido University, Tomakomai, Hokkaido 053

*****South China Academy of Tropical Crops, Baodao Xincun, Hainan Island, China
} 


\section{SITE DESCRIPTION AND CLIMATOLOGICAL BACKGROUND OF STUDY AREA}

Hainan Island, at $18^{\circ} 10^{\prime}-20^{\circ} 10^{\prime} \mathrm{N}$ and $108^{\circ} 37^{\prime}-111^{\circ} 03^{\prime} \mathrm{E}$ has an area of $33,907 \mathrm{~km}^{2}$. The annual mean temperature at Danxian, about $10 \mathrm{~km}$ east of the study area is $23.2^{\circ} \mathrm{C}$. The highest monthly mean temperature is $27.5^{\circ} \mathrm{C}$ in July, and the lowest is $16.9^{\circ} \mathrm{C}$ in January. The total annual precipitation at Danxian is $1,815.6$ $\mathrm{mm}$, and about $84 \%$ of this falls in the rainy season from May to October.

The region in this study is a gently hilly land on the upper reaches of the Beimen River (Fig. 1). The study area was established by the Third Production Team of SCATC, supported by the Japan project in Baodao Xincun in northern Hainan. The area had two study sites: one was Linduan at an experimental rubber plantation and the other was Huaguoshan at the top of an uncultivated small hill, $140 \mathrm{~m}$ above sea level, adjoining Linduan (Photo 1 [1]). The meteorological data observed at the tower of the Linduan site show characteristics of the rubber plantation and the data from Huaguoshan are regarded as the standard.

The Linduan site is located about $600 \mathrm{~m} \mathrm{WNW}$ of the Huaguoshan site. The ground is approximately $142 \mathrm{~m}$ a.s.l. and slopes gently from SE to NW. The rubber trees are $14 \mathrm{~m}$ high on an average and about 650 trees/ha. Trees acting as windbreaks are arranged around the rubber plantation, except on the NNW side. The windbreaks are 2 to $25 \mathrm{~m}$ high. The highest windbreaks are Acacia confusa and the next highest are Schima superba (Photo 1 [2]). The lower trees are Podocarpus nagi and Pariurus ramosissimus (TAKAHASHi et al., 1986).

The distance from the tower at Linduan to the windbreaks is approximately $40 \mathrm{~m}$ towards NNE and SSW (Photo 1 [3]). The windbreaks on the NNE side are effective in the winter monsoon season and those on the SSW side are important in the summer monsoon season. The windbreaks about $90 \mathrm{~m}$ ESE of the tower are 16 to $18 \mathrm{~m}$ high and rather sparse, and are effective when typhoons approach Hainan Island from the South China Sea.

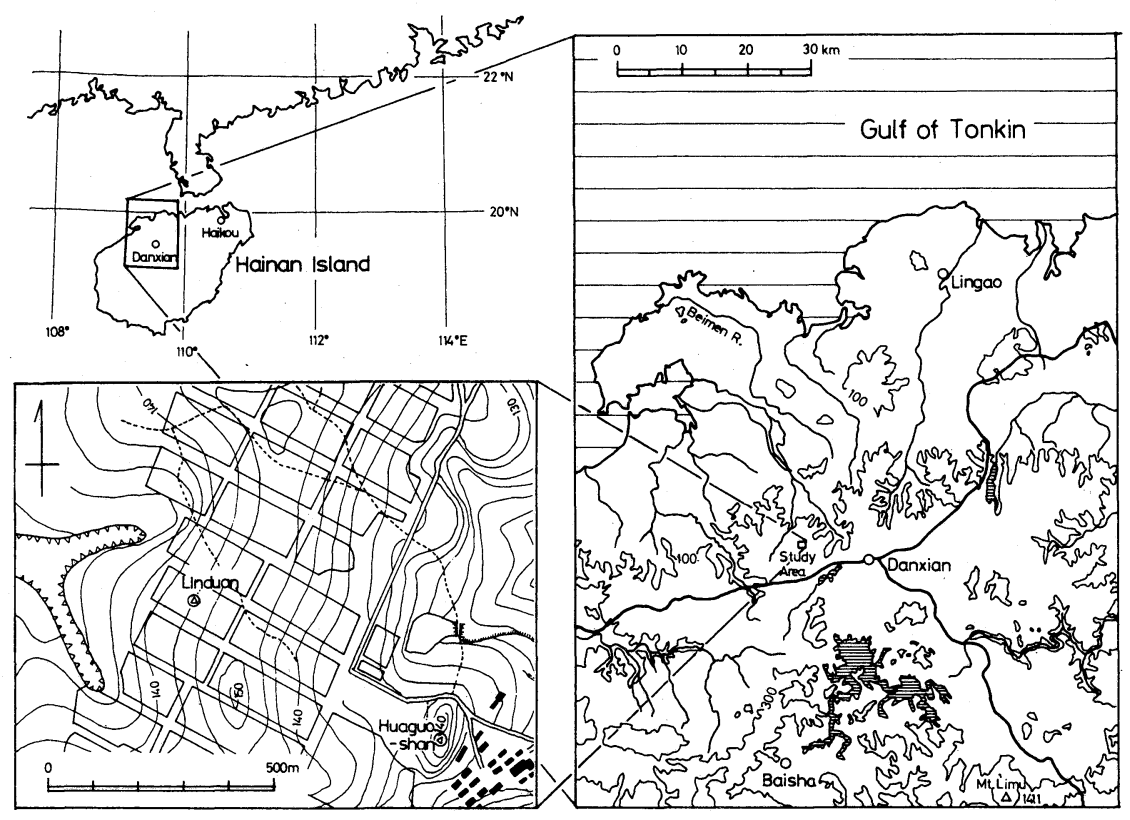

Figure 1. Geographical maps of the study area (illustrated by TAKAHASHI, YOSHINO et al., 1988) 

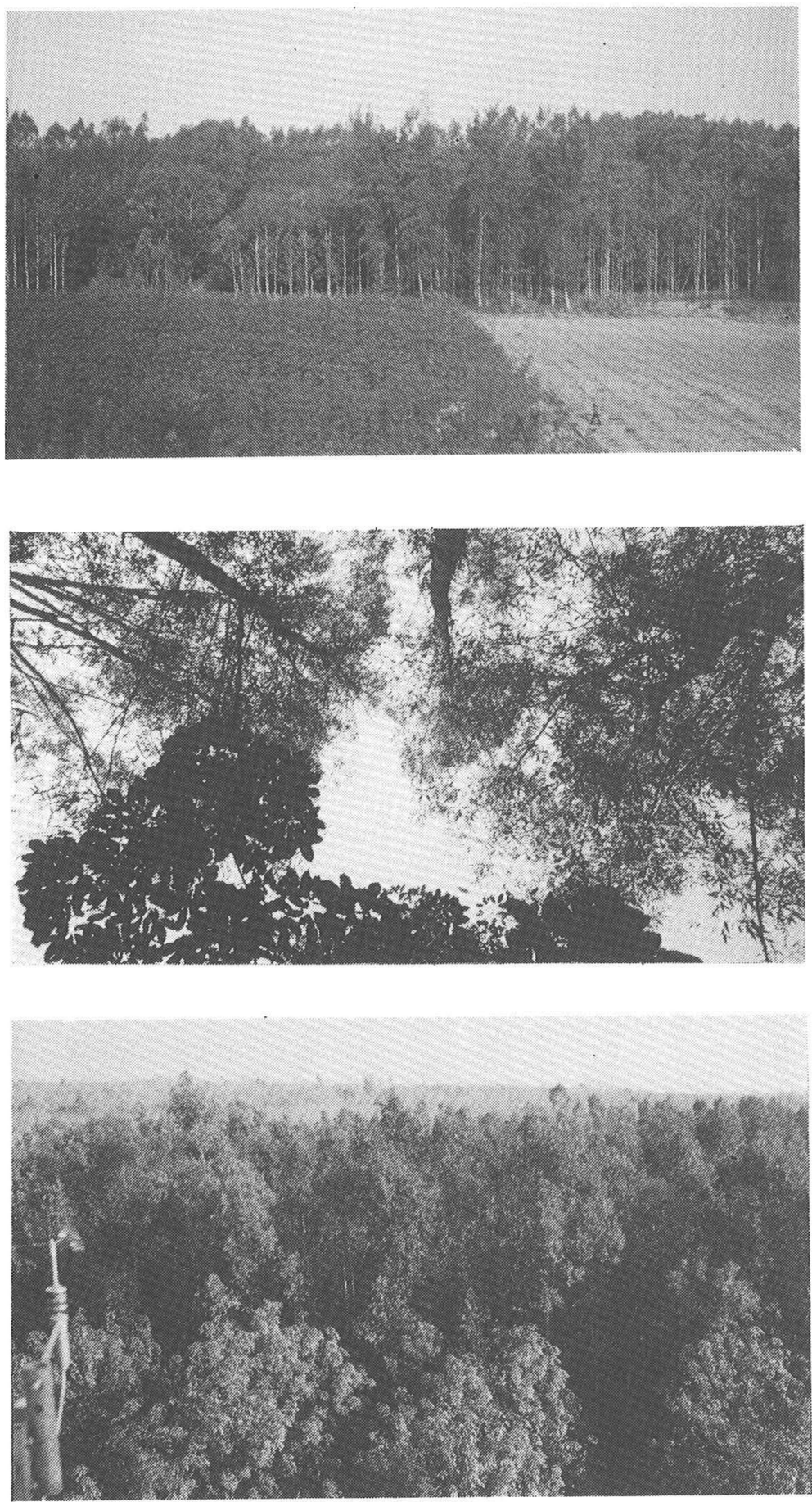

Photo 1. Landscapes of the study area taken in Jan. 1987 by S. YAMAKAWA.

[1] A landscape of the Linduan site from the Huaguoshan site. The distant views are the rubber plantation, windbreaks and an observation tower (in the upper middle). The near views are younger rubber trees and fields under cultivation. [2] Windbreaks, namely Acacia confusa (in the upper part) and Schima superba (in the lower part), taken upward. [3] Rubber trees and windbreaks Acacia confusa, etc., taken from the tower at Linduan facing SSW. 


\section{INSTRUMENTATION AND METHODS OF OBSERVATION}

Two $30 \mathrm{~m}$ high steel towers were constructed at Linduan and Huaguoshan. The $2 \mathrm{~m}$ arms with the instruments are north-south at 10 levels: 1 , $2,4,6,10,14,18,22,26$, and $30 \mathrm{~m}$. The meteorological data measured at the two sites for the three years were air temperature (all levels), trunk temperatures of rubber trees (5 levels), soil temperature ( 7 levels), water temperature of evaporimeter, air humidity (4 levels), soil moisture (5 levels), soil heat flux, solar radiation (2 levels), duration of sunshine (at Linduan only), wind direction, wind speed (10 levels), three component wind speed (2 levels), precipitation, evaporation, and atmospheric pressure (at Huaguoshan only).

All data except soil moisture were recorded digitally with a data logging system (EKO SOLAC2) and compiled by a microcomputer (NEC 8801) on a high density magnetic disk at 30-minute intervals.

The vertical flux of momentum and sensible heat above the rubber tree canopy were measured by ultrasonic anemometer (Kaijodenki, DA-100) and a fine $0.05 \mathrm{~mm}$ diameter copperconstantan thermocouple fixed at the end of an arm extending $1.5 \mathrm{~m}$ north from the tower at $18 \mathrm{~m}$, about $2 \mathrm{~m}$ above the canopy of the rubber tree stand. The data from the two sensors were recorded on a magnetic tape data recorder (Kyowa, RTP540A), and digitized using an A/D converter with a sampling interval of $20 \mathrm{~Hz}$. The observation was carried out mainly in the daytime from December 1988 to January 1989 at Linduan.

\section{RESULTS AND DISCUSSIONS}

\section{Aerodynamic properties of the rubber tree stand}

Wind profiles above the ground or vegetation surface are represented by the logarithmic law

$$
u=\frac{u_{*}}{k} \cdot \ln \frac{Z_{0}-d}{Z_{0}}
$$

where $u$ : wind speed at height $z$

$$
\begin{aligned}
& u_{*}: \text { friction velocity } \\
& d: \text { zero-plane displacement } \\
& k: \text { von Karman's constant } \\
& Z_{0}: \text { roughness parameter }
\end{aligned}
$$

The $d$ values were estimated by selecting the best $d$ values which maximized the regression coefficients between measured wind speeds at 4 levels, $u_{1}, \ldots, u_{4}$ and $\ln \left(z_{1}-d\right)$, and then the values of $Z_{0}$ were estimated. The Richardson number was calculated from air temperatures and wind speeds at two levels, 14 and 30m. Analyses were limited to $|\mathrm{Ri}|<0.03$ and $\mathrm{E}$ and ESE winds.

(a) Relation between zero-plane displacement and roughness parameter and seasonal changes in these aerodynamic wind properties above the rubber tree stand.

The roughness parameter $Z_{0}$ is derived from the zero-plane displacement $d$. Fluctuations in $d$ affect $Z_{0}$ directly. The size of $Z_{0}$ for a particular plant community represents its bulk effectiveness as an absorber of momentum, while $d$ indicates the mean level at which momentum is absorbed by individual elements of a plant community. Therefore, variations in $Z_{0}$ or $d$ from one determination to the next are negligible unless fairly substantial changes occur in mean geometry, such as might be associated with streamlining effects in strong winds (Тном, 1975). In practice there are deviations from regularity due to changes in wind speed, complex reactions of plant communities subjected to wind, and lack of homogeneity in plant distribution. TAKEDA $(1964,1966)$ derived the theoretical relationship between $Z_{0}$ and $d$ as shown in eq. (2).

$$
\ln \frac{H-d}{Z_{0}}=\frac{k}{\alpha} \cdot \frac{H-d}{H}
$$

where. $H$ : effective height of plants $\alpha$ : constant

The effective height of rubber trees can be simply estimated from eq. (2) and Fig. 2, as the value of $H$ is equal to $d$ when $Z_{0}$ is zero. The monthly mean effective height of the rubber tree stand clearly changed during the observation (Fig. 3). The effective height increased at about $0.5 \mathrm{~m}$ per year, corresponding to the annual growth of the rubber trees. The effective height decreased 


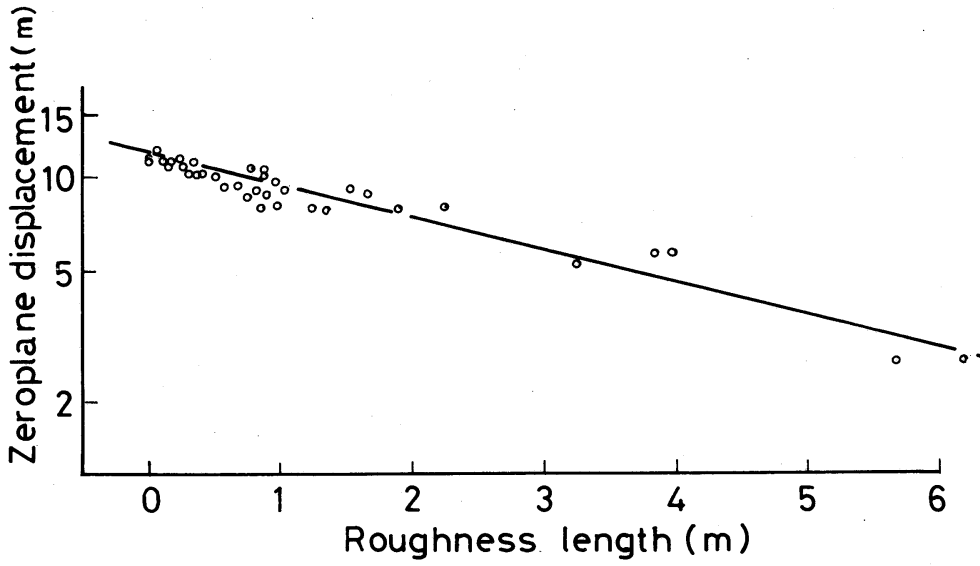

Figure 2. Relationship between $d$ and $Z_{0}$ obtained from observations (circle) and regression line (solid line)

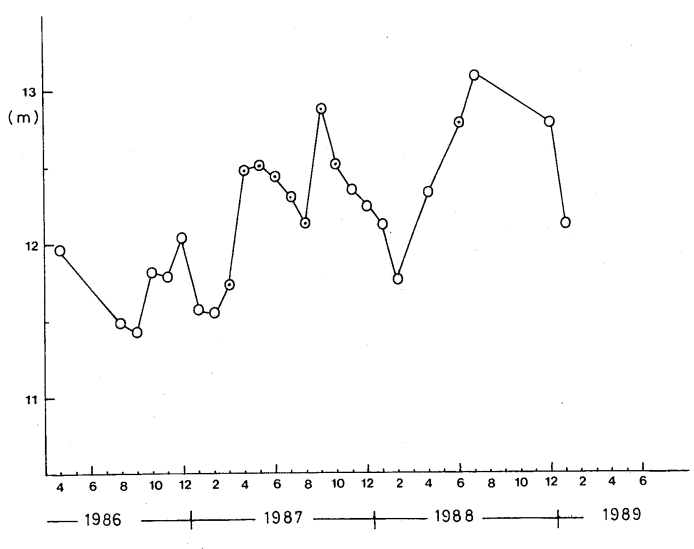

Figure 3. Seasonal change of effective height of rubber trees

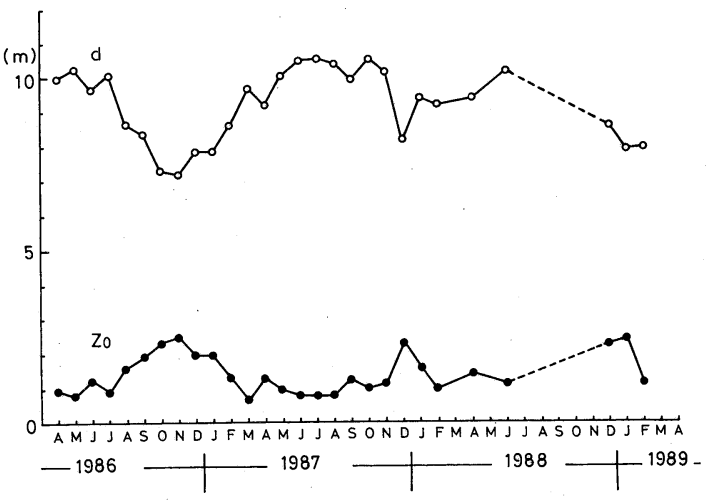

Figure 4. Seasonal changes of $\mathrm{Z}_{0}$ and $d$ of rubber tree stand

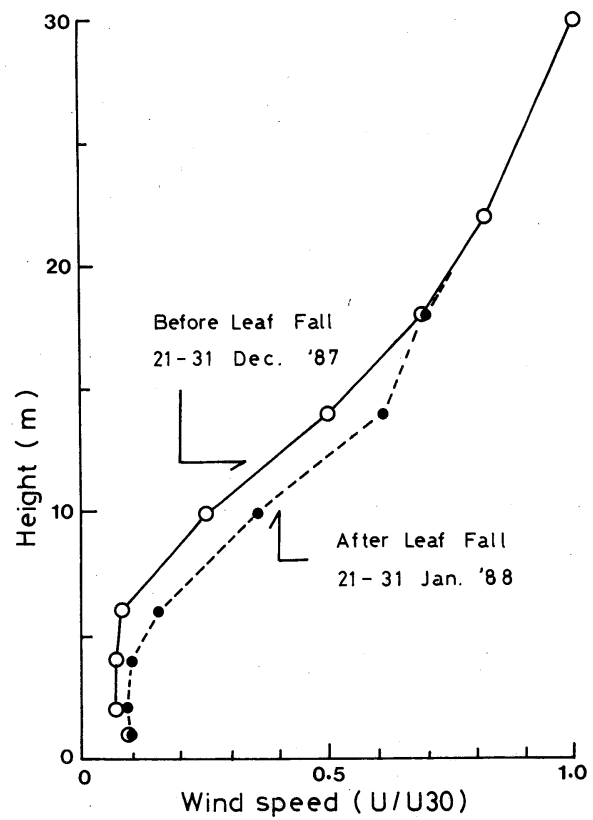

Figure 5. Wind speed profiles in and above the rubber tree stand before and after leaf fall

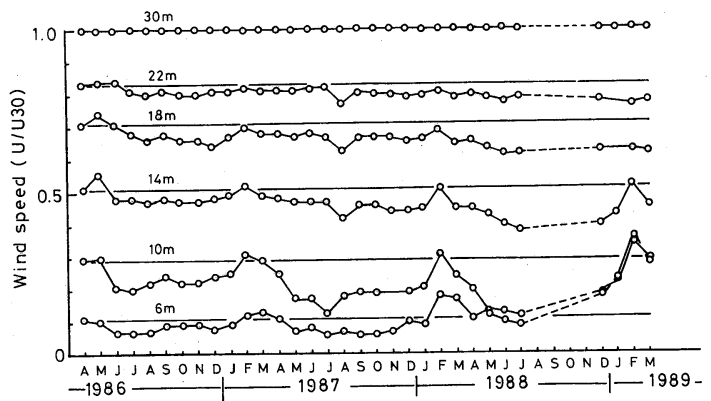

Figure 6. Seasonal changes of wind speeds in and above the rubber tree stand 
sharply in winter, January and February, and summer, August and September. The decreases in winter are considered to be caused by leaf fall. The growth rate of rubber trees drops slightly in summer (TAKAHASHI et al., 1988b), but this does not cause a decreases in the effective height.

The values of $d$ and $Z_{0}$ also change seasonally as shown in Fig. 4. The value of $Z_{0}$ decreased to $0.6-0.8 \mathrm{~m}$ in spring and early summer and increased to about $2.5 \mathrm{~m}$ in late autumn and early winter, and $d$ shows the opposite tendency. Drag of the forest canopy on wind is mainly determined by the $Z_{0}$ values, so the drag coefficient of the rubber tree forest reaches a maximum in winter, just before the trees shed their leaves.

(b) Effects of elongation and leaf and stem fall on wind profiles in and above the rubber tree stand

Fig. 5 shows the wind speed profiles in and above the canopy before and after the leaves have fallen. The wind below $14 \mathrm{~m}$, at the top of the rubber tree canopy, increased after the leaves had fallen. Fig. 6 shows monthly mean wind speeds at different levels in and above the canopy. Annual fluctuations in wind speed at $10 \mathrm{~m}$, just below the top of the canopy, was the largest because elongation and fall of leaves and stems directly affect the wind at this level. Every winter, mainly in February, the wind speed at this level shows a small peak because leaves are almost completely off and new leaves and stems start to develop in March. The wind speed above $14 \mathrm{~m}$ decreased year by year as the rubber trees were growing at about $0.5 \mathrm{~m} /$ year. At $6 \mathrm{~m}$ above the ground wind speeds gradually increased, apparently caused by the rising canopy level.

\section{Radiative properties of the rubber tree stand}

As some data are missing due to electricity failures and noise in the data it is difficult to establish the individual variations in radiation components. The present study filtered out the noisy data similarly to NAKAGAwa et al. (1988a), and determined monthly composites of diurnal variations in the radiation balance components of the rubber tree stand. In addition monthly mean daily totals for each term were obtained by summing up the half-hourly composite values.

Open circles in Fig. 7 stand for the downward solar radiation flux over the canopy of the rubber trees at $30 \mathrm{~m}$. The observations were carried out for 36 months from April in 1986 to March in 1989, but there was an electricity failure from August to November 1989. In addition, the instrument was out of order from May 1986 to November 1987 . Fortunately the downward solar radiation flux was also measured outside the rubber tree stand, $500 \mathrm{~m}$ southeast of the experimental stand, and the study replaced the downward solar radiation flux observed over the canopy top of the rubber trees with that observed outside the stand. As a result, there are 32 sets of data in Fig. 7.

The downward solar radiation is larger in summer than in winter, and as the sun reaches its

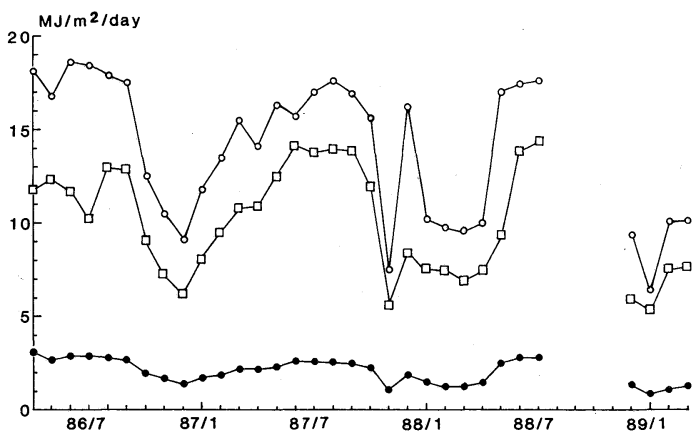

Figure 7. Monthly variations in radiation components over the canopy top of rubber trees in Hainan Island $\left(\mathrm{MJ} / \mathrm{m}^{2}\right)$. All data were measured at $30 \mathrm{~m}$ above the ground. Open and solid circles stand for downward and upward solar radiations, and open squares for net radiation.

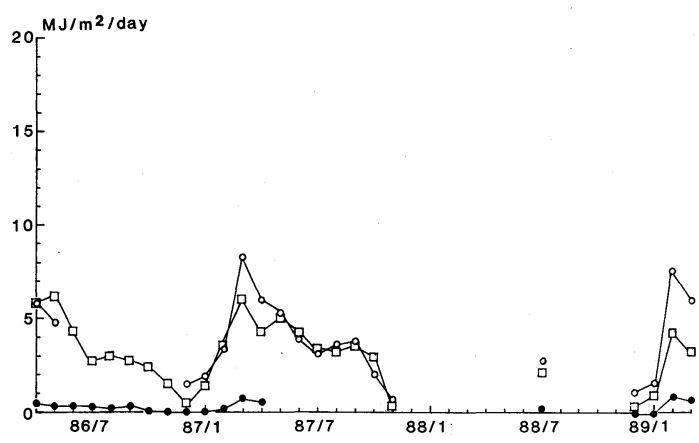

Figure 8. The same as Fig. 7, at the forest floor of rubber tree stand, measured at $4 \mathrm{~m}$ above the ground. 
zenith twice a year, in the middle of May and at the end of July, it would be expected that there should be a weak minimum in June around the summer solstice. However, there was no such minimum, except in 1987. The downward solar radiation in summer reached about $17.5 \mathrm{MJ} / \mathrm{m}^{2}$ every year, in winter there was not necessarily a minimum in December around the winter solstice, and the values varied remarkably from 16.1 $\mathrm{MJ} / \mathrm{m}^{2}$ in 1987 to $5.6 \mathrm{MJ} / \mathrm{m}^{2}$ in 1988 . It is suggested that the downward solar radiation flux in summer is similar to that in winter. The annual total downward solar radiation flux from December 1986 to November 1987 was 5156 $\mathrm{MJ} / \mathrm{m}^{2}$, larger than the $4940 \mathrm{MJ} / \mathrm{m}^{2}$ estimated from other climatological elements (GAO et al., 1986).

The solid circles in Fig. 7 are the reflected solar radiation flux over the rubber tree canopy, and data are available for 32 months. Like the downward solar radiation flux, it is larger in summer, about $3 \mathrm{MJ} / \mathrm{m}^{2}$, and smaller in winter, about $1 \mathrm{MJ} / \mathrm{m}^{2}$, and there is no summer minimum. The annual total of reflected solar radiation over the canopy from December 1986 to November 1987 was $741 \mathrm{MJ} / \mathrm{m}^{2}$.

The open squares in Fig. 7 stand for the net radiation over the canopy. Data are available for 32 months, and the annual changes in net radiation are proportional to the downward solar radiation, in summer, about $14 \mathrm{MJ} / \mathrm{m}^{2}$, and in winter, 5-8 MJ $/ \mathrm{m}^{2}$. There is no June minimum. The annual net radiation flux over the canopy from December 1986 to November 1987 was $3965 \mathrm{MJ} / \mathrm{m}^{2}$.

The open circles in Fig. 8 show the downward solar radiation flux at the forest floor, measured $4 \mathrm{~m}$ above the ground. The instrument was out of order twice from May to November 1986 and from December 1987 to June 1988. As a result, there are only data for 19 months. The downward solar radiation flux at the forest floor shows a clear annual change. It is small, about $1 \mathrm{MJ} / \mathrm{m}^{2}$, in midwinter, increases rapidly after the end of winter to reach $8 \mathrm{MJ} / \mathrm{m}^{2}$ in spring. It then gradually decreases until the next midwinter. The rapid increase is downward solar radiation between late winter and early spring is possibly due to the leaf fall, as suggested by NAKAGAWA et al. (1988b). The annual total downward solar flux at the forest floor from December 1986 to November 1987 was 1329 $\mathrm{MJ} / \mathrm{m}^{2}$.

The solid circles in Fig. 8 are the reflected solar radiation at the forest floor of the rubber trees. The instrument was out of order from May 1987 to June 1988 , and only 18 months' data is available. Solar radiation reflected by the forest floor is very small. The downward solar radiation reaching the forest floor is very small especially in winter, it is too small to be measured accurately and shows negative values. As a result the total reflected solar radiation from December 1986 to November 1987 can be neglected.

The open squares in Fig. 8 show the net radiation at the forest floor of the rubber tree stand. Since the instrument was out of order from December 1987 to June 1988, data are available for 25 months only. Annual changes in net radiation flux at the forest floor are very similar to those in the downward solar radiation flux at the same height. This suggests that the long-wave radiation at the forest floor of rubber tree stands is in equilibrium. The annual total net radiation at the forest floor from December 1986 to November 1987 was $1171 \mathrm{MJ} / \mathrm{m}^{2}$.

Fig. 9 shows month-to-month variations in the radiation balance of the canopy layer of the rubber trees. Open circles show the short-wave radiation balance of the canopy layer. Data from December 1987 to June 1988 is missing, and the study considers it zero, the result is 19 sets of data in Fig. 9. The heat gain of the canopy layer of rubber trees is larger in summer and smaller in other seasons. The summer maximum exceeded $11 \mathrm{MJ} / \mathrm{m}^{2}$. The annual total short-wave radiation on the canopy of the rubber trees from December 1986 to November 1987 reached 3086 $\mathrm{MJ} / \mathrm{m}^{2}$.

The open squares in Fig. 9 are 25 sets of data for the total radiation balance of the canopy of the rubber trees. It is clear that the annual total wave radiation balance is very similar to the short-wave radiation balance. In other words, the radiation balance of the canopy layer consists chiefly of absorption of solar radiation. The annual total radiation balance from December 1986 to November 1987 was $2793 \mathrm{MJ} / \mathrm{m}^{2}, 293$ $\mathrm{MJ} / \mathrm{m}^{2}$ smaller than the absorption of solar radiation. 


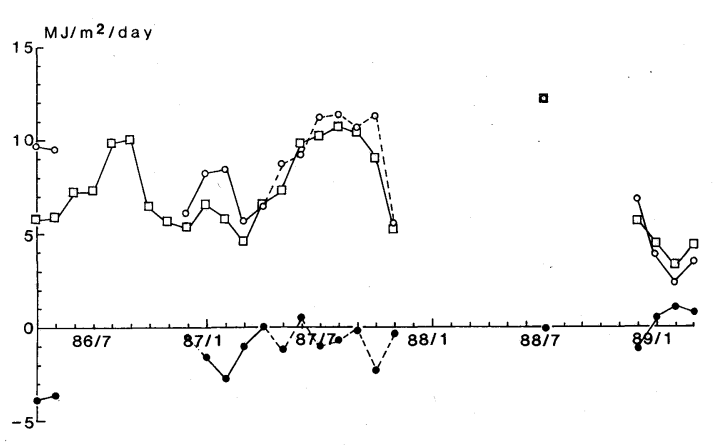

Figure 9. Monthly variations in radiation components of radiation balance of the canopy layer of rubber trees in Hainan Island $\left(\mathrm{MJ} / \mathrm{m}^{2}\right)$. Open circles stand for short-wave radiation balance of canopy layer of rubber trees, solid circles for long-wave radiation balance.

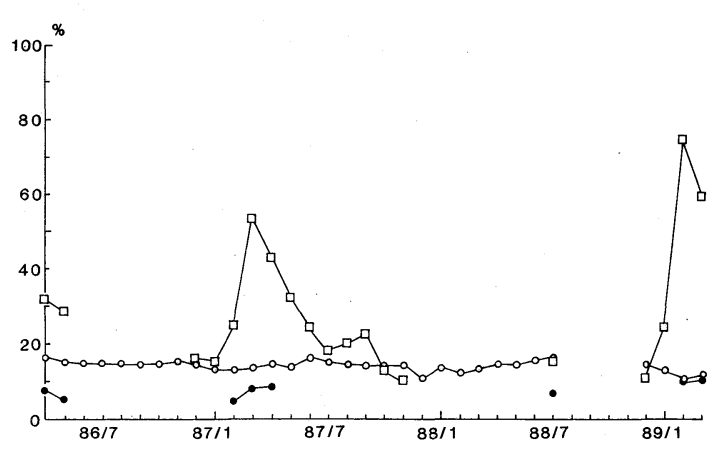

Figure 10. Monthly variations in albedo and penetration ratio of the rubber tree stand in Hainan Island (\%). Open circles stand for the forest floor, and open squares for penetration ratio of the canopy.

The difference between the total and shortwave radiation must be the long-wave radiation, and the solid circles in Fig. 9 show the long-wave radiation balance of the canopy layer. This term was always negative or very small, remarkably less than the short-wave radiation balance, varying from $-4 \mathrm{MJ} / \mathrm{m}^{2}$ to $1 \mathrm{MJ} / \mathrm{m}^{2}$.

Fig. 10 shows month-to-month changes in some radiation properties of the rubber tree stand. Open circles are the albedo of the canopy, obtained by dividing the upward solar radiation flux $30 \mathrm{~m}$ above the ground by the downward solar radiation flux at the same height. It varies from $10 \%$ to $16 \%$, and is smaller in winter and spring and larger in summer and autumn. The annual mean albedo, obtained from the annual total for one year from December 1986 to November 1987, was $14.4 \%$.

The solid circles in Fig. 10 stand for the albedo at the forest floor of the rubber tree stand, obtained by dividing the upward solar radiation flux $4 \mathrm{~m}$ above the ground by the downward solar radiation flux at the same height. Since there were many missing or inaccurate data, only 8 sets of data are available. It is clear that the albedo of the forest floor is smaller than that of the canopy top, except for the winter in 1989. This is because the downward solar radiation at the forest floor consists chiefly of diffuse radiation, whereas downward solar radiation over the canopy consists of both direct and diffuse radiation. In general, the albedo of diffuse radiation is independent of the solar elevation, and considerably smaller than the direct radiation (FujImoto, 1975). In Fig. 10 the difference between the canopy top and forest floor albedos decreases at the end of winter and early spring when leaf fall occurs.

Open squares in Fig. 10 indicate the penetration of the canopy layer. This ratio is obtained by dividing the downward solar radiation flux at $4 \mathrm{~m}$ above the ground by that at $30 \mathrm{~m}$. Compared with the albedo, the penetration ratio shows clear annual changes; it is small and about the same as for the albedo of the top of the canopy at the end of winter, and then rapidly increases, to a maximum in early spring. The ratio at the spring maximum was $74.8 \%$ in February 1989 , and $53.7 \%$ in 1987 . Unfortunately, the number of leaves dropped by rubber trees has not been observed continuously at our observation site. However, the drastic change in the penetration ratio of the canopy layer is possibly a result of shedding of leaves, as shown by NAKAGAWA et al. (1988b).

\section{Turbulent heat flux in and above the rubber tree stand}

The energy budget above a rubber tree stand is determined by the energy balance and eddy correlation methods. The sensible heat flux $H$ was obtained as 


$$
H=C_{p} \rho \overline{W^{\prime} \cdot \theta^{\prime}}
$$

where $\omega$ is the air density, $C_{\mathrm{p}}$ is the specific heat capacity, $W^{\prime}$ and $\theta^{\prime}$ are the vertical wind speed and temperature. The primes denote fluctuations from the mean and the bar represents the time average. The latent heat flux was calculated on the basis of the energy balance formula with $H$ derived from the above equation.

\section{(a) Characteristics of turbulent fluxes}

Time series variations of vertical wind speed and air temperature show large fluctuations because the air layer above the rubber tree stand was unstable (Fig. 11). The two curves are approximately similar, but vertical wind speeds show high frequencies because they are more sensitive to wind speed fluctuations than the thermocouple. The spectrum peak of the vertical wind component is within $0.05-0.1 \mathrm{~Hz}$ (Fig. 12). (b) Turbulent heat flux and its changes with leaf fall

Cold waves invaded the study area several times during the observation period. During one from Jan. $12-16,1989$ the air temperature
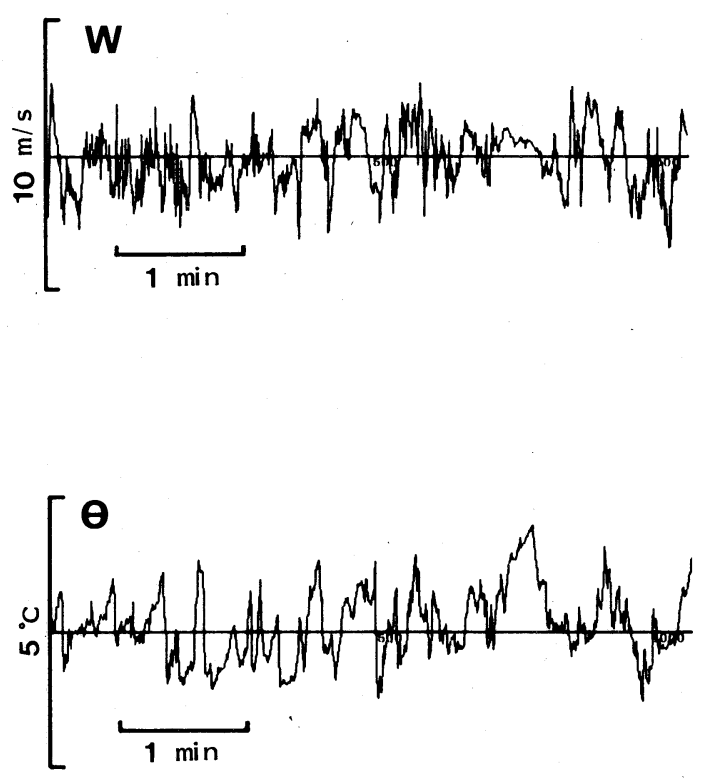

Figure 11. Time series fluctuation of vertical wind speed and air temperature at $18 \mathrm{~m}$ high above the ground, about $2 \mathrm{~m}$ high above the canopy top dropped remarkably and caused many leaves to fall (Fig. 13). The daily number of fallen leaves increased abruptly after Jan. 18 and reached 200 leaves $/ \mathrm{m}^{2}$ on Jan. 19. The diurnal sensible and latent heat flux above the canopy before and after the catastrophic leaf fall were calculated (Fig. 14). The weather on Jan. 7, before the leaf fall, was fine. Relative humidity was $45-63 \%$ and wind speed at $18 \mathrm{~m}$ above the ground was $1.0-2.4 \mathrm{~m} / \mathrm{sec}$ in the daytime. Sensible and la-

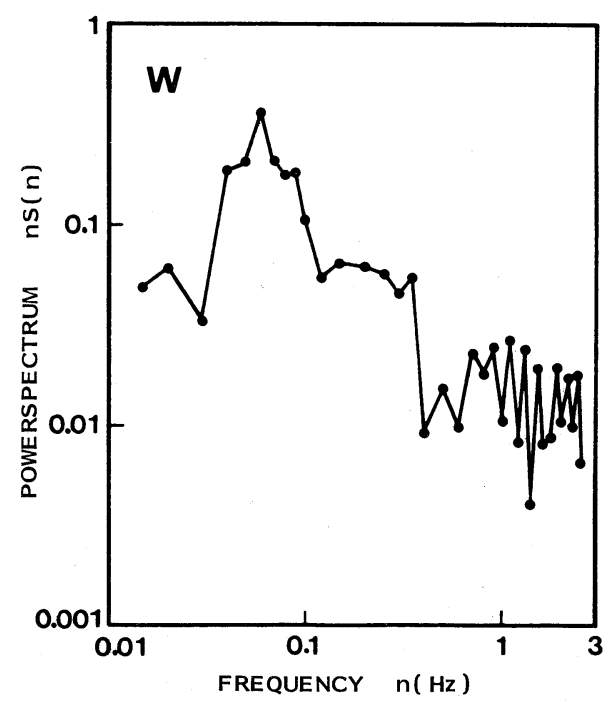

Figure 12. Power spectrum of vertical wind speed

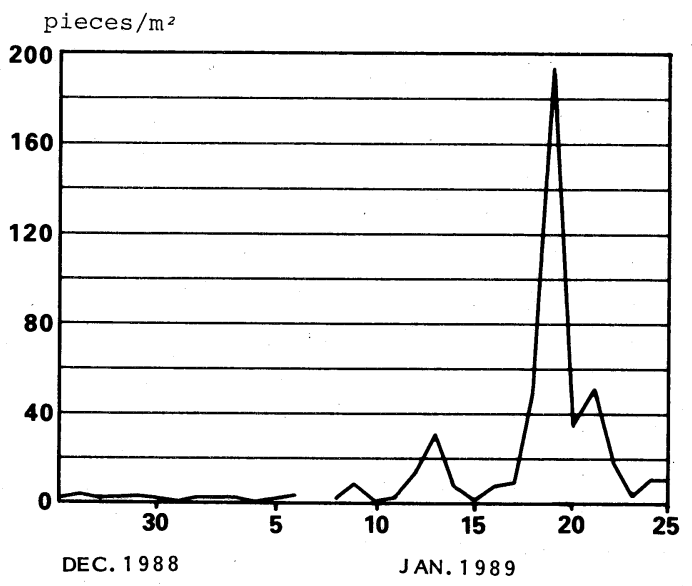

Figure 13. Daily amounts of leaf fall from rubber trees on the Linduan site 

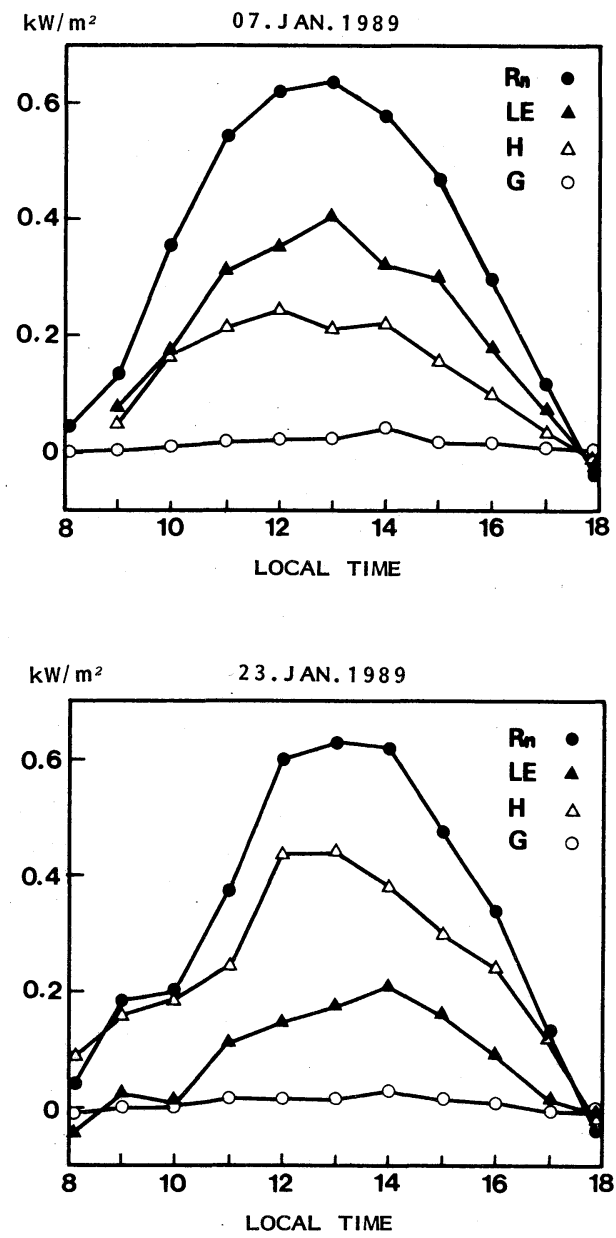

Figure 14. Diurnal change of heat balance above the canopy of rubber trees before and after leaf fall

$\mathrm{Rn}$ : net radiation, $\mathrm{H}$ : sensible heat flux, LE: latent heat flux, G: soil heat flux.

tent heat on that day were $37 \%$ and $59 \%$ of net radiation. The weather on Jan. 23, after the leaf fall, was also fine except a few clouds in the morning. Relative humidity was $54-61 \%$ and wind speed was $1.9-3.6 \mathrm{~m} / \mathrm{sec}$ in the daytime, approximately similar to Jan. 7. The sensible heat flux represented $73 \%$ of the net radiation, while the latent heat flux was only $24 \%$. The latent heat flux after the leaf fall had obviously decreased below that before the leaf fall. The decrease appears to be caused by the reduction of transpiration through the leaves. Sensible heat increased after the leaf fall, and the results show that the cold wave influences the heat balance through the leaf fall.

\section{Heat balance of the forest floor in the rubber tree stand}

Temperature profiles above the canopy showed inversions at night and lapse conditions during the day. However, temperature conditions in the forest differed remarkably from those above the canopy. Foliage was dense above the forest floor, and temperature profiles in the rubber tree stand showed inversions during the day and lapse conditions at night and on clear days. The lapse rate was the inversion (negative lapse rate, $-1.6^{\circ} \mathrm{C} / 10 \mathrm{~m}$ ) during the day and dry adiabatic (greater than $0.1^{\circ} \mathrm{C} / 10 \mathrm{~m}$ ) at night above the forest floor on Jan. 7, 1989. The cold winter monsoon occurred on Jan. 14, 1989, and the atmosphere was neutral or slightly unstable $\left(0.5^{\circ} \mathrm{C} / 10 \mathrm{~m}\right)$ with overcast and with drizzle all through the day. Fig. 15 shows the RicHARDSON number used as an index of stability. Comparing $\mathrm{Ri}$ on clear days with that of a typical cold winter monsoon in Fig. 15, the instability all through the day during the cold winter monsoon on Jan. 14, 1989 is especially remarkable. The stable condition during the day and unstable condition at night on the clear day Jan. 9, 1989 characteristically appeared above the forest floor.

Fig. 16 shows the heat balance components in the cold winter monsoon compared with those

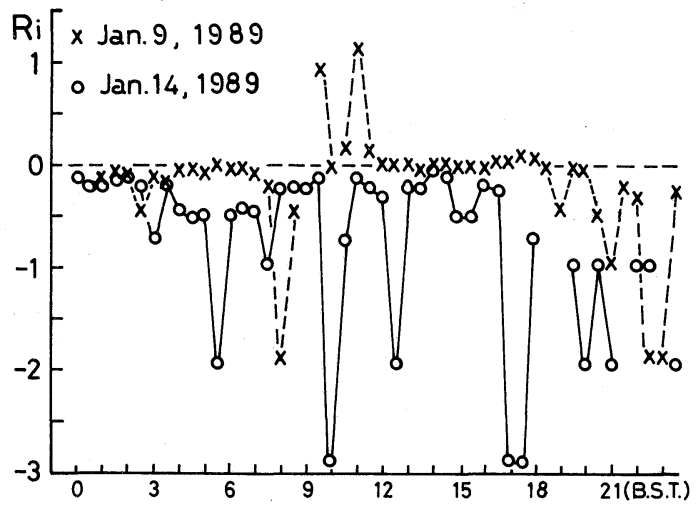

Figure 15. Variations of Ri number with time Broken line: Jan. 9, 1989, on a clear day; solid line: Jan. 14,1989 , on a cold winter monsoon day. 

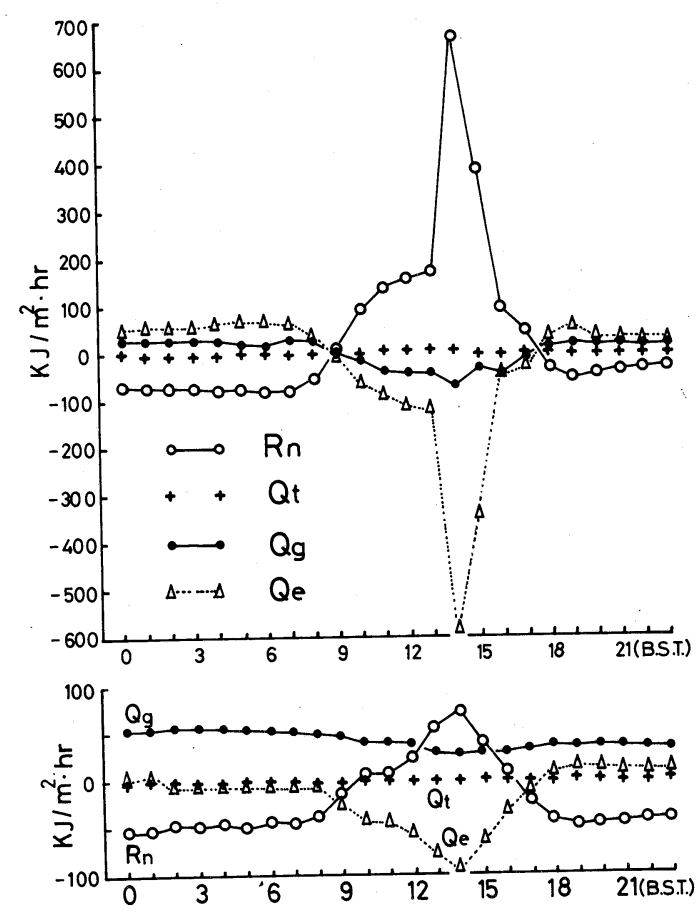

Figure 16. Variations of heat balance components on Jan. 9, 1989 (above) and Jan. 14, 1989 (below)

$\mathrm{Rn}$ : net radiation, Qt: sensible heat flux, Qe: latent heat flux, Qg: conductive heat flux.

on clear days, for representative days chosen from about 40 days of measurements.

At the height above the forest canopy $\mathrm{Z}$, heat balance at the ground surface is described by the following equation (MuNN, 1966):

$$
R n+Q t+Q e+Q g=0
$$

where the flux towards the surface is regarded as positive and that away from the surface as negative. $Q t$ and $Q e$ are the sensible heat flux, and the latent heat flux of evaporation or condensation; $Q g$ is the conductive heat flux from and into the ground. The quantities of net radiation $R n$ and conductive heat flux $Q g$ were to be measured directly at $4 \mathrm{~m}$ above the ground and on the ground surface. The $Q t$ value was obtained using the relation

$$
Q t+K \cdot \Delta T \cdot U
$$

where $K$ is an empirical constant $\Delta T$ is the temperature difference between $4 \mathrm{~m}$ and $1 \mathrm{~m}$; $U$ the wind speed at 4m (IsHIKAWA et al. 1982); Qe was estimated from equation (4) as the remainder of the other components. On the cold winter monsoon day of Jan. 14, the reduction in net radiation to the forest floor is illustrated in Fig. 16. The sensible heat flux was very small throughout the day and the heat loss due to negative net radiation was compensated by the conductive heat flux on the ground during the night. During the day, the total heat supply of positive net radiation and conductive heat flux appeared to be used preferentially for evaporation. On the clear day of Jan. 9, both the sensible and conductive heat were too small to compensate for the heat loss of the negative net radiation at night. Therefore, the latent heat flux compensated for the heat loss of the negative net radiation. Positive net radiation during the day approximately balanced the latent heat flux. Consequently all components at the forest floor reached only small values.

The heat balance on a clear day above the forest floor is shown in the energy budget components in Fig. 17, and on a cold monsoon day

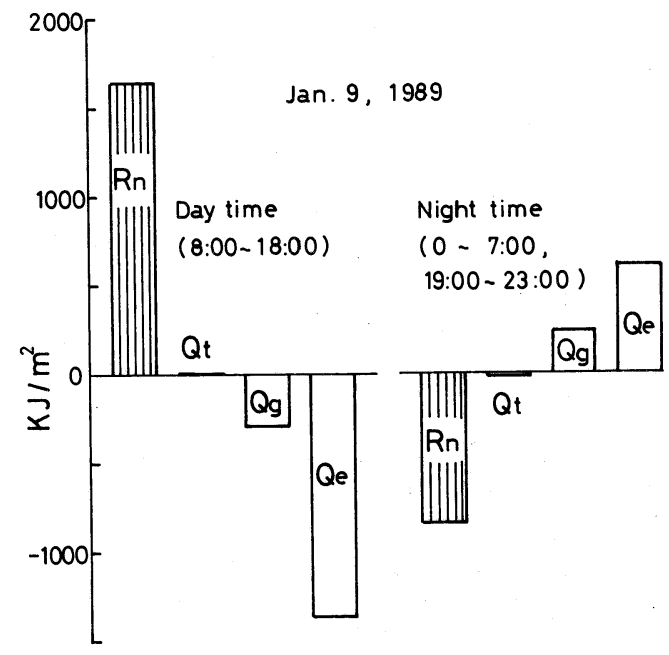

Figure 17. Comparison of the heat balance components on a clear day above the forest floor 


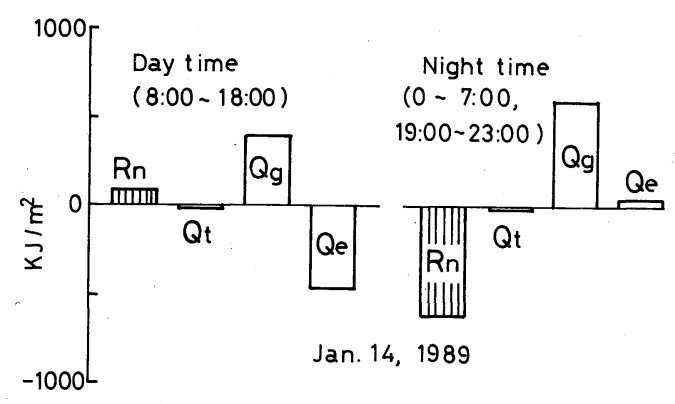

Figure 18. Same as Fig. 17 except on a cold winter monsoon day

in Fig. 18. On the clear day, the positive net radiation at the forest floor was only $28.6 \%$ of that above the canopy during the daytime and the negative net radiation was only $12.2 \%$ of that during the night. But on the cold monsoon day, the negative net radiation at the forest floor was more than 4 times larger than above the canopy during the night. Fig. 17 shows that the energy contribution is quite different from that obtained above the canopy during the night. Furthermore, on cold monsoon days the value of the conductive heat was characteristically vigorous both day and night, as in Fig. 18. The heat loss due to net radiation was compensated satisfactorily by the conductive heat without a falling ground surface temperature at the forest floor.

\section{CONCLUSION}

Micrometeorological properties of a rubber tree plantation were measured for three years and from April 1986 to March 1989 in Hainan Island. Two iron towers were constructed in- and outside of a rubber tree plantation. Air and soil temperatures, air humidities, short wave radiations and reflections, net radiations, wind speed, wind directions etc., were measured on the towers.

Aerodynamic and radiative properties, and heat balance in and above the rubber tree stand were analyzed using those data. Several conclusions can be drawn from the results:

(1) The effective height of the rubber tree stand derived from TAKEDA's formula (eq. 2) increased gradually year by year. But the effective height decreased sharply in winter after leaf fall.

(2) Roughness parameter $Z_{0}$ of the rubber tree stand decreased to $0.6-0.8 \mathrm{~m}$ in spring and early summer, and increased to about $2.5 \mathrm{~m}$ in late autumn and early winter. On the other hand, zero-plane displacement $d$ showed the opposite tendency with the $Z_{0}$ values.

(3) Short wave and net radiations on the forest showed clearly the annual change. Those increased rapidly in late winter with leaf fall and after that decreased gradually until mid-winter.

(4) The albedo of the rubber tree stand also changed from $10 \%$ to $16 \%$. It was small in winter and spring, and large in summer and autumn.

(5) Latent heat flux above the canopy decreased and sensible heat flux increased drastically after leaf fall caused by strong cold wave invasion.

(6) The sensible heat flux was very small on the forest floor through a day.

(7) During the day, the total heat supplied by the positive net radiation and the soil heat flux seem to be used preferentially for evaporation.

\section{Acknowledgements}

The authors wish to express their appreciation to Professor HuANG Zondao, President of the South China Academy of Tropical Crops and to the staff of the academy for their kind aid and advice. Special thanks are extended to Professor Masatoshi YosHINO, University of Tsukuba, Professor JIANG Ailiang, Academia Sinica and Mr. WANG Peicheng, South China Academy of Tropical Crops for their reviews and valuable suggestions.

(Received Oct. 14, 1989)

(Accepted Jan. 15, 1990)

\section{References}

FUjImoto, F. (1975): Influence of atmospheric pollution on the solar radiation measured on the ground (I). $\mathrm{Ge}$ ophys. Mag., 37, 1-48.

GaO, S., HuAnG, Z., Zhang, T. and Lin, X. (1986): The climate of Hainan Island. Science Press, 189.

Ishikawa, N., Kobayashi, S. and Kojima, K. (1982): Measurement of sensible heat flux in the snow-melting season 1. Low Temp. Sci., A-41, 109-116.

HAO, Y. (1981): Full and rational use of Hainan's agroclimatic resources, Agrometeorology, 2.

HuAnG, Z., GaO, S. and Lin, X. (1985): Microclimatic features in rubber plantations of Hainan Island, Jour. Tropical Meteor., 11, 364-376.

MunN, R.E. (1966): Descriptive Micrometeorology. Academic Press, 242 p.

Nakagawa, K., TaKahashi, H., Yamakawa, S., HaO, 
Y. and XIE, L. (1988a): Radiation balance of rubber tree stand in Hainan Island in winter. Jour. Climatol.ogical Notes, 38, 35-48.

Nakagawa, K., Takahashi, H., Yamakawa, S., Makita, H., Chujo, H., HaO, Y. and XIE, L. (1988b): Effect of leaf fall on radiative environments in and above the canopy layer of rubber tree stand, Climatol. Notes, 38, 49-54.

Takahashi, H., Makita, H., Nakagawa, K., Hayashi, Y., Hao, Y., Xie, L., Wang, P., Wei, F. and YAO, M. (1986): Micrometeorology in rubber plantation during cold wave weather conditions. Climatol. Notes, 35, 37-58.

Takahashi, H., NaKagawa, K., Yamakawa, S., HaO, Y., XIE, L. and WANG, P. (1988a): The effect of windbreaks on the wind properties in and above the canopy of rubber tree stand in Hainan Island, Climatol. Notes, 38, 17-26.

Takahashi, H., NaKagawa, K., Yamakawa, S., Makita, H., Chujo, H., HaO, Y. and XIE, L. (1988b): Annual changes of aerodynamic properties of rubber tree stand in Hainan Island, Climatol. Notes, 38, $17-26$.

TAKEDA, K. (1964): Turbulence in plant canopies, Jour. Agr. Meteor., 20, $1-5$.

TAKEDA, K. (1966): On roughness length and zero-plane displacement in the wind profile of lowest air layer, Jour. Meteor. Soc. Japan, 44, $101-107$.

XIE, L. (1982): Cold damage of rubber tree and the methods of prevention, Qixiang, 8 .

YoSHINO, M. (1986): Some aspects of climate, geoecology and agriculture in Hainan Island and Xishuangbanna, in South CHina, Climatol. Notes, 35, 5-33.

Yoshino, M., Jiang, A., HaO, Y., Takahashi, H., Nakagawa, K., YamaKawa, S., Makita, H., ChUJO, H., XIE, L. and WANG, P. (1988): System of micrometeorological observation in and out of a rubber plantation in Hainan Island. Climatol. Notes, $\mathbf{3 8}$, $5-16$.

\title{
中国海南島のゴム園における微気象特性
}

\author{
高橋英 紀*, 中川清隆**, 山川修治***, \\ 田中夕美子*, 前田佳 則*, 郝 永 路****, \\ 謝羅 乃 $* * * *$, 王 $* * * *$, 曾平****
}

中国海南島の北部にゴムの木のプランテーションが展 開されている農場 (林段) があるが，そこで 1986 年 4 月 から 1989 年 3 月までの 3 年間に 観測されたデータを基 に, 微気象特性を調べた。粗度, 地面修正量, ゴム林の キャノピーを通過する放射透過率など空気力学的パラメ 一ターは，落葉前後で明らかに異なる。キャノピー上の 短波放射のアルベードは，冬季には $10 \%$ であるが，夏
季と秋季には $16 \%$ になる。落葉後, キャノピー上の顕 熱フラックスが増加すると, 潜熱フラックスは急激に減 少する。林床上に拈ける顕熱フラックスは 1 日を通して 非常に小さい。また，夜間には，負の正味放射による熱 の損失があるが，それは地熱フラックスにより補償され ることなどが明らかとなった。

* 干060 北海道札幌市, 北海道大学環境科学研究科

** T934 新潟県上越市, 上越教育大学学校教育学部

*** 个305 茨城県つくば市, 筑波大学地球科学系

**** $\bar{\top} 053$ 北海道苫牧小市, 北海道大学農学部演習林 ***** 中国海南島, 華南熱帯作物研究院 